\title{
Distribution of the M129V polymorphism of the prion protein gene in a Turkish population suggests a high risk for Creutzfeldt-Jakob disease
}

\author{
Nihan Erginel-Unaltuna ${ }^{1}$, Katell Peoc' ${ }^{2}{ }^{2}$, Evrim Komurcu ${ }^{1}$, Tufan Tevfik Acuner ${ }^{3}$, \\ Halim Issever ${ }^{4}$ and Jean-Louis Laplanche ${ }^{*, 2}$
}

${ }^{1}$ Department of Genetics, Institute for Experimental Medical Research, Istanbul University, Istanbul, Turkey; ${ }^{2}$ Service de Biochimie et Biologie Moléculaire, Association Claude Bernard, Hôpital Lariboisière, Paris, France; ${ }^{3} 3$ rd Neurology Clinic, Turkish Ministry of Health Bakirkoy Hospital for Psychiatric and Neurological Diseases, Istanbul, Turkey; ${ }^{4}$ Division of Biostatistics and Demography, Department of Public Health, Istanbul Medical School, Istanbul University, Istanbul, Turkey

A polymorphism (M129V) at codon 129 of the prion protein gene (PRNP) results in either a methionine residue (Met) or a valine residue (Val) and is known to determine susceptibility for the development of sporadic or acquired Creutzfeldt-Jakob disease (CJD). The distributions of M129V genotypes and alleles in various general populations have been reported and there are clear differences between Western Europeans and East Asians. We analysed the coding sequence of the PRNP gene in 100 healthy Turkish subjects to determine whether the distributions of the M129V genotypes and alleles or other PRNP gene variants in the Turkish population differ from those in other normal populations. Three known polymorphisms but no other gene variants were detected in the PRNP coding sequence of the Turkish individuals. Genotype frequencies at codon 129 were $57 \%$ Met/Met, 34\% Met/Val and 9\% Val/Val, with an allele frequency of $0.740: 0.260$ Met:Val. These distributions are considerably different from those reported for other normal populations residing in Western Europe and East Asia, except in Crete. The higher frequency of 129 Met-homozygotes in Turkey than in Western Europe suggests that the Turkish are at greater risk of developing CJD. European Journal of Human Genetics (2001) 9, 965-968.

Keywords: Creutzfeldt-Jakob disease; prion; gene; PRNP; polymorphism; Turkey; population; genetic

\section{Introduction}

Prion diseases are a group of fatal neurodegenerative diseases including Creutzfeldt-Jakob disease (CJD) in humans and bovine spongiform encephalopathy (BSE) in cattle. ${ }^{1}$ They manifest themselves as sporadic, inherited or infectious (iatrogenic, acquired) disorders. ${ }^{1}$ The main event in their pathogenesis appears to be the conversion of the prion protein

*Correspondence: Jean-Louis Laplanche, Service de Biochimie, Hôpital Lariboisière, 2 rue A. Paré, 75475 Paris Cedex 10, France. Tel: +331 4995 64 34; Fax: +331499584 77;

E-mail: jean-louis.laplanche@Irb.ap-hop-paris.fr

Received 28 August 2001; revised 9 November 2001; accepted 9 November 2001
(PrP), a normal cellular protein, to an abnormal isoform. ${ }^{1}$ Insertions and point mutations in the prion protein gene (PRNP, MIM *176640), located on chromosome 20 in humans, are associated with inherited prion diseases (see database at www.mad-cow.org/prion_point_mutations.html). A common polymorphism (M129V) at codon 129 of the PRNP gene results in either a methionine residue (Met) or a valine residue (Val) and is known to determine susceptibility for the development of sporadic, ${ }^{2-5}$ iatrogenic $^{6}$ or variant $^{7}$ CJD (vCJD). vCJD is believed to be linked with exposure to the BSE agent. Homozygosity for Met at codon 129 is a high risk factor for CJD, being detected in $70-75 \%$ of Caucasians with sporadic $\mathrm{CJD}^{2-5}$ and all patients with vCJD tested to date. 
The distributions of M129V genotypes (Met/Met, Met/Val or $\mathrm{Val} / \mathrm{Val}$ ) and alleles (Met or Val) in various general populations $^{3-9}$ show clear differences between Western Europeans and East Asians. Thus, it would be of particular interest to explore the distribution of these genotypes in population residing at the boundary between Europe and Asia, such as Turkey. We therefore analysed the sequence of the PRNP gene in a sample of healthy Turkish subjects to determine whether the distributions of M129V genotypes and alleles, or other PRNP gene variants in the Turkish population differ from those in other normal populations. Knowledge about the genetic background of the Turkish should enable us to evaluate their susceptibility to CJD.

\section{Materials and methods}

Genomic DNA was extracted by standard techniques from the peripheral blood leukocytes of 100 unrelated healthy Turkish subjects (50 women and 50 men selected from various regions of Turkey, mean age $30 \pm 10$ years). The PRNP coding sequence was amplified by PCR as previously described ${ }^{10}$ and the PCR products were separated on a $6 \%$ neutral polyacrylamide gel and examined for size variations before direct sequencing. ${ }^{10}$ In case of the detection of a size variation, the normal and variant fragments were firstly eluted from the gel, then sequenced. In order to confirm the genotypes of some individuals, at codons 117,129 and at position -21 in the intron sequence flanking the $5^{\prime}$ end of exon $2\left(-21 \mathrm{~A} / \mathrm{G}^{11}\right)$, a fragment containing the three polymorphisms was amplified using forward primer $5^{\prime}$ GTTCACCCTTTTCTTCATTTTG-3' and reverse primer 5'TGATGGGCCTGCTCATGGCAC-3' in standard PCR conditions, then submitted to the endonuclease restriction enzymes PvuII and Tail. The chi-square test was used to compare genotype and allele frequencies in normal populations. All significance values are two-tailed.

\section{Results and discussion}

Variations in the PRNP gene and the potential influence of these variations onto susceptibility to CJD have never been studied in the Turkish population, which is located at the boundary between Europe and Asia. We studied 100 Turkish individuals and found three polymorphisms in the coding sequence. Two subjects (2\%) were found to carry a 24 base pair (bp) deletion between repeats $\mathrm{R} 3$ and $\mathrm{R} 4$ in the octapeptide coding region. Twenty-four bp deletions in the octapeptide coding region of $P R N P$ which spans codons 51 to 91, are rare non-pathogenic polymorphisms, and have previously been reported in North African ${ }^{12}$ and Japanese ${ }^{13}$ individuals as well as in Western Europeans, ${ }^{14}$ with an allelic frequency of about $0.5 \%$ in the latter population. These deletions are probably generated by unequal crossing-over between normal alleles.

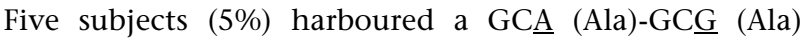
substitution at codon 117 . This substitution is a silent mutation that does not modify the coding amino acid alanine but alters a $P v u I I$ restriction site. This polymorphism is present in around $11 \%$ of Western Europeans (UnitedKingdom $\left.{ }^{11}\right)$. However, it has never been found in East Asians including 62 Han Chinese subjects from Taïwan, ${ }^{9}$ and a small number of Japanese $(n=16)$, Thai $(n=11)$ and Nepalese $(n=8)$ individuals. $^{15}$

The genotype frequencies at codon 129, ATG(Met)/ GTG(Val), in the Turkish population were $57 \%$ Met/Met, $34 \% \mathrm{Met} / \mathrm{Val}$ and $9 \% \mathrm{Val} / \mathrm{Val}$, with an allele frequency of 0.740:0.260 Met:Val (see Table 1). No significant deviation from the Hardy-Weinberg equilibrium was observed $\left(\chi^{2}=0.64 ; \mathrm{df}=2 ; P=0.73\right)$. The frequencies of the Met/Met genotype at codon 129 and of the Met allele were significantly higher in the Turkish population than those reported in a pooled Caucasian population ${ }^{5}$ (respectively, $\left.\chi^{2}=10.50, \mathrm{df}=2, \quad P=0.005 ; \chi^{2}=7.03, \mathrm{df}=1, \quad P=0.008\right)$ and those found in Western European countries such as the United Kingdom ${ }^{2}$ (respectively, $\chi^{2}=8.48, \mathrm{df}=2, \quad P=0.014$; $\chi^{2}=6.51, \mathrm{df}=1, P=0.011$ ), France $^{3,16}$ (respectively, $\chi^{2}=8.32$, $\left.\mathrm{df}=2, \quad P=0.016 ; \quad \chi^{2}=5.03, \quad \mathrm{df}=1, \quad P=0.025\right)$ and Spain $^{17}$ (respectively, $\chi^{2}=7.44, \mathrm{df}=2, \quad P=0.024 ; \chi^{2}=8.02, \mathrm{df}=1$, $P=0.005)$. The Met/Met genotype was also overrepresented in Turkish individuals compared to Austrian ${ }^{18}$ individuals $\left(\chi^{2}=6.79, \mathrm{df}=2, P=0.034\right)$, although the frequency of the

Table 1 Genotype and allele frequencies at codon 129 of the PRNP gene in control populations

\begin{tabular}{|c|c|c|c|c|}
\hline \multirow[b]{2}{*}{ Populations } & \multirow[b]{2}{*}{$\mathrm{n}$} & \multicolumn{2}{|c|}{ Genotypes n (\%) } & \multirow{2}{*}{$\begin{array}{c}\text { Allele frequency } \\
\text { Met : Val }\end{array}$} \\
\hline & & Met/Met : Met/Val : Val/Val & $\mathrm{Hm}: \mathrm{Ht}$ & \\
\hline Turkish & 100 & $57(57): 34(34): 9(9)$ & $66(66): 34(34)$ & $0.740: 0.260$ \\
\hline Pooled Caucasians 5 & 398 & $156(39): 198(50): 44(11)$ & $200(50): 198(50)$ & $0.641: 0.359$ \\
\hline British $^{2}$ & 106 & $39(37): 54(51): 13(12)$ & $52(49): 54(51)$ & $0.623: 0.377$ \\
\hline French ${ }^{3,16}$ & 161 & $63(39): 82(51): 16(10)$ & $79(49): 82(51)$ & $0.646: 0.354$ \\
\hline Spanish $^{17}$ & 268 & $112(42): 113(42): 43(16)$ & $155(58): 113(42)$ & $0.629: 0.371$ \\
\hline Austrian $^{18}$ & 300 & $129(43): 146(49): 25(8)$ & $154(51): 146(49)$ & $0.673: 0.327$ \\
\hline Italian ${ }^{4}$ & 186 & $84(45): 75(40): 27(15)$ & $111(60): 75(40)$ & $0.653: 0.347$ \\
\hline Cretan $^{19}$ & 205 & $117(57): 77(37.6): 11(5.4)$ & $128(62.4): 77(37.6)$ & $0.759: 0.241$ \\
\hline Japanese $^{8}$ & 179 & $164(92): 15(8): 0(0)$ & $164(92): 15(8)$ & $0.958: 0.042$ \\
\hline Han Chinese ${ }^{9}$ & 100 & $97(97):$ & $97(97): \quad 3(3)$ & $0.985: 0.015$ \\
\hline
\end{tabular}

Met=methionine; Val=valine; $\mathrm{Hm}=$ homozygous for methionine or valine; $\mathrm{Ht}=$ heterozygous. 
Met allele did not differ in these two populations $\left(\chi^{2}=3.12, \mathrm{df}=1, \quad P=0.077\right)$. Conversely, there was no difference in the frequency of the M129V genotypes in Turkish and Italian $^{4}$ populations $\left(\chi^{2}=4.10, \mathrm{df}=2, P=0.13\right)$, although the Met allele was significantly more frequent in Turkish individuals than in Italians $\left(\chi^{2}=4.53, \mathrm{df}=1\right.$, $P=0.033)$. In contrast, nearly identical genotypes and allele frequencies (respectively, $\chi^{2}=1.59, \mathrm{df}=2, P=0.45$; $\left.\chi^{2}=0.25, \mathrm{df}=1, \quad P=0.62\right)$ were observed in the Turkish group and in native individuals from Crete ${ }^{19}$ which is geographically close to Asia Minor.

Following the observation that the $-21 \mathrm{~A}-117 \mathrm{Ala}(\mathrm{GCG})$ 129Val PRNP allele represents 5.6\% of the alleles of British subjects, ${ }^{11}$ we used restriction endonuclease digestion with PvuII and TaiI (Tail cuts at position -21 when the intron sequence contains the $G$ variant and at codon 129 when it encodes valine) to explore coupling between the three polymorphisms in Turkish. The results indicated that all the five Turkish individuals who carried the GCG variant at codon 117 had also, as British, the rare A intron variant at position -21 , both located on the same $129 \mathrm{Val}$ allele. Interestingly, this association is also present in French individuals (K Peoc'h and J-L Laplanche, unpublished results) and therefore suggests a possible unique origin of the rare -21A-117Ala(GCG)-129Val PRNP allele before its spread throughout Europe.

Considerable differences in genotype and allele frequencies were also observed between Turkish and Eastern Asian populations such as the Japanese ${ }^{8}$ (respectively, $\left.\chi^{2}=49.80, \mathrm{df}=2, \quad P=0.0001 ; \chi^{2}=57.77, \mathrm{df}=1, \quad P=0.0001\right)$ and Han Chinese $^{9}$ (respectively, $\chi^{2}=45.36, \quad \mathrm{df}=2, \quad P=0.0001$; $\left.\chi^{2}=50.61 \mathrm{df}=1, P=0.0001\right)$. The Val allele, which has a frequency of 0.26 in Turkey and $0.35-0.38$ in Western Europe, is rare in Japanese (frequency=0.04) and Chinese populations (frequency=0.01). The frequencies of the 129Met and 129Val alleles in Turkey and in East Asia could represent the limits of a west-to-east gradient of PRNP in Asia, a well-established characteristic for many other genes reflecting the Caucasoid-Mongoloïd gradient as a consequence of ancient human migration throughout Asia. $^{20}$

Consequently, the distributions of the M129V genotypes and alleles in the Turkish population differ considerably from those reported for other normal populations residing in either Western Europe or East Asia, with the notable exception of Cretan natives. A recent report ${ }^{19}$ found that the high rate of PRNP $129 \mathrm{Met}$ homozygosity in Crete was associated with a local increase in the incidence of sporadic CJD. As homozygosity at PRNP codon 129 is a recognized risk factor for sporadic and acquired CJD in Caucasians ${ }^{5,21}$ and heterozygosity is protective, ${ }^{2-4,21}$ the higher frequency of 129Met-homozygotes in Turkey than in Western Europe would also suggest that the Turkish are at increased risk of developing CJD.

\section{Acknowledgments}

This study was held on behalf of the Prion Diseases Study Group in Turkey and supported by the Scientific and Technical Research Council of Turkey (TUBITAK, grant no: 196S104/SBAG-1666) and by the Turkish Psychiatry Association. We thank Martine Lenne for excellent technical assistance.

\section{References}

1 Prusiner SB: Shattuck lecture-neurodegenerative diseases and prions. N Engl J Med 2001; 344: 1516-1526.

2 Palmer MS, Dryden AJ, Hughes JT, Collinge J: Homozygous prion protein genotype predisposes to sporadic CreutzfeldtJakob disease [published erratum appears in Nature 1991; 352: 547]. Nature 1991; 352: 340-342.

3 Laplanche J-L, Delasnerie-Lauprêtre N, Brandel JP et al: Molecular genetics of prion diseases in France. Neurology 1994; 44: $2347-2351$

4 Salvatore M, Genuardi M, Petraroli R, Masullo C, D'Alessandro M, Pocchiari M: Polymorphisms of the prion protein gene in Italian patients with Creutzfeldt-Jakob disease [published erratum appears in Hum Genet 1995; 95: 605]. Hum Genet 1994; 94: $375-379$.

5 Alpérovitch A, Zerr I, Pocchiari M et al: Codon 129 prion protein genotype and sporadic Creutzfeldt-Jakob disease [published erratum appears in Lancet 2000; 355: 72]. Lancet 1999; 353: 1673 - 1674. Letter.

6 Collinge J, Palmer MS, Dryden AJ: Genetic predisposition to iatrogenic Creutzfeldt-Jakob disease. Lancet 1991; 337: 1441 1442 .

7 Zeidler M, Ironside JW: The new variant of Creutzfeldt-Jakob disease. Rev Sci Tech 2000; 19: 98-120.

8 Doh-ura K, Kitamoto T, Sakaki Y, Tateishi J: CJD discrepancy. Nature 1991; 353: 801-802.

9 Tsai MT, Su YC, Chen YH, Chen CH: Lack of evidence to support the association of the human prion gene with schizophrenia. Mol Psychiatry 2001; 6: 74-78.

10 Peoc'h K, Manivet P, Beaudry P et al: Identification of three novel mutations (E196K, V203I, E211Q) in the prion protein gene $P R N P$ in inherited prion diseases with Creutzfeldt-Jakob disease phenotype. Hum Mutat 2000; 15: 482.

11 Palmer MS, van Leeven RH, Mahal SP, Campbell TA, Humphreys $\mathrm{CB}$, Collinge J: Sequence variation in intron of prion protein gene, crucial for complete diagnostic strategies. Hum Mutat 1996; 7: 280-281. Letter.

12 Laplanche J-L, Chatelain J, Launay JM, Gazengel C, Vidaud M: Deletion in prion protein gene in a Moroccan family. Nucleic Acids Res 1990; 18: 6745.

13 Yamada $\mathrm{M}$, Itoh $\mathrm{Y}$, Fujigasaki $\mathrm{H}$ et al: Deletion in the prion protein gene in a Japanese family. Biomed Res (Tokyo) 1994; 15: $131-133$.

14 Palmer MS, Mahal SP, Campbell TA et al: Deletions in the prion protein gene are not associated with CJD. Hum Mol Genet 1993; 2: $541-544$

15 Doh-ura K, Tateishi J, Sasaki H, Kitamoto T, Sakaki Y: Pro $\rightarrow$ leu change at position 102 of prion protein is the most common but not the sole mutation related to Gerstmann-Straussler syndrome. Biochem Biophys Res Commun 1989; 163: 974-979.

16 Deslys JP, Marcé D, Dormont D: Similar genetic susceptibility in iatrogenic and sporadic Creutzfeldt-Jakob disease. J Gen Virol 1994; 75: $23-27$.

17 Combarros O, Sanchez-Guerra M, Llorca J et al: Polymorphism at codon 129 of the prion protein gene is not associated with sporadic AD. Neurology 2000; 55: 593-595.

18 Zimmermann K, Turecek PL, Schwarz HP: Genotyping of the prion protein gene at codon 129. Acta Neuropathol (Berl) 1999; 97: $355-358$ 
19 Plaitakis A, Viskadouraki AK, Tzagournissakis et al: Increased incidence of sporadic Creutzfeldt-Jakob disease on the island of Crete associated with a high rate of PRNP 129-methionine homozygosity in the local population. Ann Neurol 2001; 50: $227-233$.

20 Cavalli-Sforza L, Menozzi P, Piazza A: The history and geography of human genes. Princeton: Princeton University Press, 1994, pp $205-254$.
21 Deslys JP, Jaegly A, d'Aignaux JH, Mouthon F, Billette de Villemeur T, Dormont D: Genotype at codon 129 and susceptibility to Creutzfeldt-Jakob disease. Lancet 1998; 351: 1251. Letter. 